\title{
Susceptibility-weighted imaging in familial cerebral cavernous malformations
}

Figure 1 Axial T2*-weighted gradient echo MRI sequence showing multiple cerebral cavernous malformations

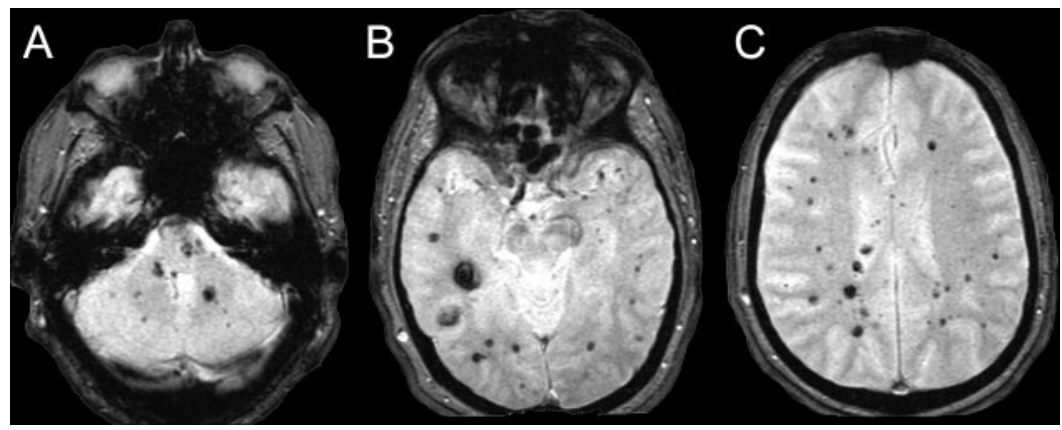

A 59-year-old man with a family history of cerebral cavernous malformations (CCM) presented with focal seizures. T2*-weighted gradient echo (GRE) images showed multiple lesions consistent with cavernous malformations (figure 1). Susceptibility-weighted images (SWI) detected nearly triple the number of lesions than were seen with the GRE sequence (figure 2).

SWI is a relatively new MRI technique that is optimized for detection of magnetic susceptibility effects. ${ }^{1}$ SWI is more sensitive than T2*-weighted GRE images in detecting CCMs. ${ }^{2,3}$ As with GRE techniques, SWI demonstrates "blooming" of hemosiderin containing lesions. ${ }^{3}$ SWI may prove to be useful in identifying the true extent of CCMs or in confirming the presence of suspected small CCMs.

Figure 2 Axial susceptibility-weighted MRI sequence showing nearly triple the number of cerebral cavernous malformations when compared to conventional T2*-weighted gradient echo MRI sequence

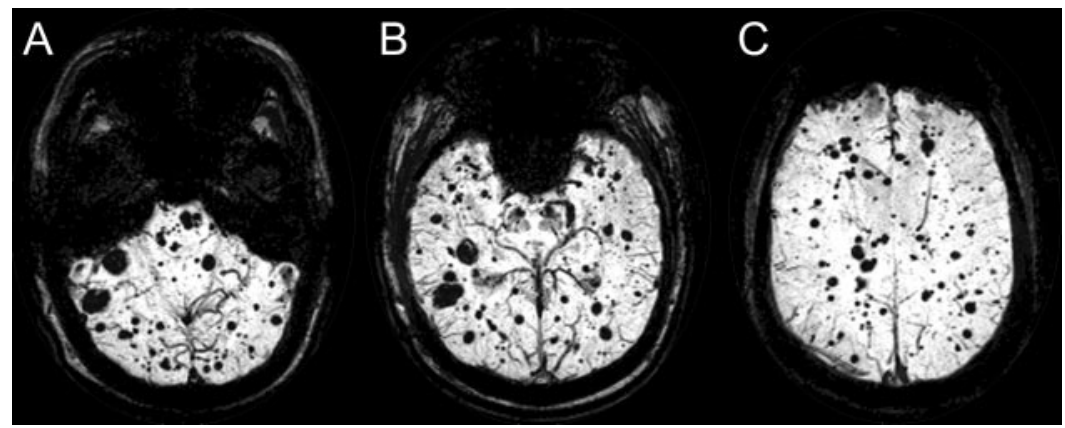

Alex D. Cooper, MD, Norbert G. Campeau, MD, and Irene Meissner, MD, Rochester, $M N$

Disclosure: The authors report no disclosures.

Address correspondence and reprint requests to Dr. Alex D. Cooper, Department of Neurology, Mayo Clinic, 200 1st Street SW, Rochester, MN55905; cooper.alex@mayo.edu

1. Sehgal V, Delproposto Z, Haacke EM, et al. Clinical applications of neuroimaging with susceptibility-weighted imaging. J Magn Reson Imaging 2005;22:439-450.

2. De Souza JM, Domingues RC, Cruz LC, et al. Susceptibility-weighted imaging for the evaluation of patients with familial cerebral cavernous malformations: a comparison with T2-weighted fast spin-echo and gradient-echo sequences. AJNR Am J Neuroradiol Epub 2007 Oct 18.

3. Akter M, Hirai T, Hiai Y, et al. Detection of hemorrhagic hypointense foci in the brain on susceptibility-weighted imaging: clinical and phantom studies. Acad Radiol 2007;14:1011-1019. 


\section{Neurology}

\section{Susceptibility-weighted imaging in familial cerebral cavernous malformations Alex D. Cooper, Norbert G. Campeau and Irene Meissner \\ Neurology 2008;71;382 \\ DOI 10.1212/01.wnl.0000319659.86629.c8}

This information is current as of July 28, 2008

\section{Updated Information \& Services}

References

Citations

Subspecialty Collections

Permissions \& Licensing

Reprints including high resolution figures, can be found at: http://n.neurology.org/content/71/5/382.full

This article cites 2 articles, 0 of which you can access for free at: http://n.neurology.org/content/71/5/382.full\#ref-list-1

This article has been cited by 1 HighWire-hosted articles: http://n.neurology.org/content/71/5/382.full\#\#otherarticles

This article, along with others on similar topics, appears in the following collection(s):

All Epilepsy/Seizures

http://n.neurology.org/cgi/collection/all_epilepsy_seizures All Genetics

http://n.neurology.org/cgi/collection/all_genetics

Arteriovenous malformation

http://n.neurology.org/cgi/collection/arteriovenous_malformation MRI

http://n.neurology.org/cgi/collection/mri

Information about reproducing this article in parts (figures,tables) or in its entirety can be found online at:

http://www.neurology.org/about/about_the_journal\#permissions

Information about ordering reprints can be found online:

http://n.neurology.org/subscribers/advertise

Neurology ${ }^{\circledR}$ is the official journal of the American Academy of Neurology. Published continuously since 1951, it is now a weekly with 48 issues per year. Copyright. All rights reserved. Print ISSN: 0028-3878. Online ISSN: 1526-632X.

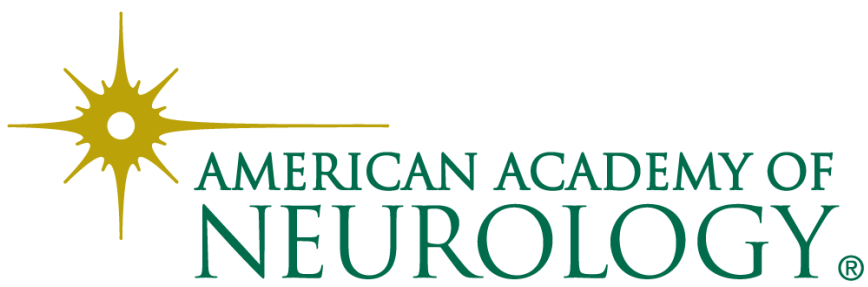

